\title{
COMPARISON OF EFFECTS OF SEVERAL INHALATION ANAESTHETICS ON CAFFEINE-INDUCED CONTRACTURES OF NORMAL AND MALIGNANT HYPERTHERMIC SKELETAL MUSCLE
}

\author{
Blverley A. Britt, Laszlo Endrenyi. Wanda Frodis, Elizabeth Scot7, \\ AND WERNER Kalow
}

\begin{abstract}
We have compared the combined effects of halothane, enflurane, isoflurane and methoxyflurane on caffeine-induced contractures of normal and malignant hyperthermia susceptibie (MHS) skeletal muscle fascicles. We have found that caffeine contractures without and with the addition of any of these four anaesthetics are higher in MHS than in normal muscle. The differences between the normal and MHS muscle are about the same for all drug combinations. For all four anaesthetics the degree of increase of the contracture is about the same in the normal as in the MHS muscle. For both the MHS and the normal muscle the caffeine contractures are from greatest to least: halothane $>$ isoflurane $>$ enflurane $>$ methoxyflurane. Examination of the relationships among the caffeine specific concentrations in the presence of the various anaesthetics shows significant differences for the comparisuns of halothane with the other three anaesthetics but, for the most part, the comparisons among methoxyflurane, enflurane and isoflurane are not meaningful statistically.
\end{abstract}

Rectert Surverst.2 (Table I) indicate that enflurane and cyclopropane may be less lethal precipitators of malignant hyperthermia $(\mathrm{MH})$ in susceptible patients than are halothane and some other potent inhalational agents. In Table I, however, the sample sizes for all anaesthetics, except halothane, are very small. To try to put this scanty clinical data on a more solid quantitative footing, we have compared the in vitro effects of halothane, enflurane, isoflurane and methoxyflurane on caffeine-induced contractures of malignant hyperthermia susceptible (MHS) and normal muscle fascicles. Cyclopropane and dicthyl ether have not been examined because of difficulty in handling such explosive agents in our laboratory and because clinical use of cyclopropane and diethyl ether in Canada has now fallen almost to the vanishing point.

Permission for the excision of human skeletal muscle was obtained from the Human Ex-

Beverley A. Britt, M.D., F.R.C.P.(C), Associate Professor, Department of Anaesthesia, University of Toronto; Associate Professor, Department of Pharmacology, University of Toronto; Senior Staff Anaes. thetist, Toronto General Hospital, Toronto, Ontario, Canada. Laszlo Endrenyi, Ph.D., Professor, Department of Pharmacology, University of Toronto; Associate Professor, Department of Preventive Medicine and Biostatistics, University of Toronto. Toronto, Ontario, Canada. Wanda Frodis, B.A., Laboratory Technician, Department of Anaesthesia. Elizabeth Scott, M.Sc., Laboratory Technician, Department of Anaesthesia. Werner Kalow, M.D., Professor, Department of Pharmacology, University of Toronto. 12
TABLE I

Maligiant Hyperthermia Mortality ASSOCIATED WITH INHALAIIONAI ANAESTHETKC AGLNTS*†

\begin{tabular}{lcc}
\hline & \multicolumn{2}{c}{ Number of patients } \\
\cline { 2 - 3 } \multicolumn{1}{c}{ Agent } & Died & Survived \\
\hline Halothane & 157 & 50 \\
Methoxyflurane & 10 & 4 \\
Enflurane & 2 & 4 \\
Trichloroethylene & 1 & 0 \\
Ethylene & 1 & 0 \\
Diethyl ether & 8 & 3 \\
Cyclopropane & 4 & 7 \\
\hline
\end{tabular}

*Cases in which iwo or more inhalational agents were administered were omitted from this tabulation.

tFor halothane vs cyclopropane $\chi^{2}=$ $6.51\left({ }_{*}\right)$.

Reproduced from Malignant Hyperthermia, Currenr Concepts, edited by E.O. Henschel, courtesy Appleton-Century-Crofts.

perimentation Committee of the University of Toronto. Each patient gave his or her written and verbal informed consent for the surgical procedure.

\section{Methods}

\section{Patient classification}

Control patients were those individuals displaying at $37^{\circ} \mathrm{C}$ normal contracture (increases in resting tension) of their skeletal muscle fascicles 
BRITT, at al.: MHS: ANAESTHETICS AND CAFFEINE-INDUCED CONTRACTURES

TABLE II

Caffeint Specific Concentrations: in the Presence and Absence of Anaesthetics

\begin{tabular}{|c|c|c|c|c|c|}
\hline & \multicolumn{5}{|c|}{ Caffeine with } \\
\hline & - & Methoxyflurane & Enflurane & lsoflurane & Halothane \\
\hline $\begin{array}{l}\text { Control } \\
\text { Patients }\end{array}$ & $\frac{6.85 \pm 0.42^{1}}{(34)^{\prime}}$ & $\begin{array}{c}5.04 \pm 0.41 \\
(19)\end{array}$ & $\begin{array}{c}3.69 \pm 0.55 \\
(16)\end{array}$ & $\begin{array}{c}3.24 \pm 0.75 \\
(10)\end{array}$ & $\frac{1.92 \pm 0.13}{(31)}$ \\
\hline $\begin{array}{l}\text { MHS } \\
\text { Patients }\end{array}$ & $\frac{2.42 \pm 0.25^{\mathrm{b}}}{(20)^{\mathrm{c}}}$ & $\begin{array}{c}1.82 \pm 0.28 \\
(11)\end{array}$ & $\begin{array}{c}1.49 \pm 0.32 \\
(9)\end{array}$ & $\begin{array}{c}1.23 \pm 0.32 \\
(11)\end{array}$ & $\begin{array}{c}0.62 \pm 0.09 \\
(20)\end{array}$ \\
\hline Ratio & $2.82 \pm 0.32^{1}$ & $2.77 \pm 0.45$ & $2.48 \pm 0.66$ & $2.64 \pm 0.97$ & $3.12 \pm 0.44$ \\
\hline$t^{t}$ & $9.70 \ddagger$ & $6.82 \ddagger$ & $3.85 \dagger$ & $3.08^{*}$ & 8.727 \\
\hline
\end{tabular}

aThe concentration required to raise the resting skeletal muscle tension by one gram.

"Geometric mean \pm its standard error.

"Number of subjects.

"t-statistic comparing caffeine specific concentrations of patients and controls. The levels of statistical significance are based on Duncan's multiple range test.

$* P<0.05$.

$+\mathrm{P}<0.01$.

$\pm \mathrm{P}<0.00$ !

in the presence of caffeine and of caffeine plus halothane, ${ }^{3-5}$ normal ATP depletion ratios of their skeletal muscle, ${ }^{4}$ and normal appearance of their skeletal muscle microscopic sections. ${ }^{6}$

Malignant Hyperthermic Susceptible (MHS) patients were subjects exhibiting at $37^{\circ} \mathrm{C}$ greater than normal contractures of their skeletal muscle fascicles in the presence of caffeine and of caffeine plus halothane, ${ }^{3-5}$ normal ATP depletion ratios of their skeletal muscle, ${ }^{4}$ and normal appearance of their skeletal muscle microscopic sections. ${ }^{6}$

Anaesthetic and Surgical Techniques, Transportation of Muscle, Specimens, Preparation and Mounting of Muscle Fascicles

Anaesthesia, surgery, the transportation of the excised muscle and the preparation and mounting in $37^{\circ} \mathrm{C}$ Krebs Ringer solution of ten isometric muscle fascicles were performed as described in reference 5 .

Equilibrations of the Skeletal Muscle Fascicles

Duplicate equilibrations of the fascicles with anaesthetic vapours were performed as follows:

chamber I - MAC* halothane $(0.8$ volume per cent)

chamber II - MAC enflurane (1.68 volumes per cent)

chamber III - MAC isoflurane ( 0.9 volume per cent)

${ }^{*}$ Minimum anaesthetic concentration. chamber IV - MAC methoxyflurane volume per cent)

chamber $\mathrm{V}$ - no anaesthetic vapour.

For some patients insufficient muscle was available to enable all four vapours to be assessed. For these individuals the two or three anaesthetics which were measured were chosen at random

In chambers I to IV, after 20 minutes equilibration with the anaesthetic vapour and with the equilibration still continuing, the Krebs Ringer Solutions were removed and replaced with fresh Krebs Ringer Solutions containing the same type and concentration of anaesthetic plus $0.25 \mathrm{mM}$ of caffeine. After a further four minutes the Krebs Ringer Solution was removed and replaced with a fresh Krebs Ringer Solution, again containing the same anaesthetic vapour plus $0.5 \mathrm{mM}$ of caffeine. This process was repeated with progressively increasing doses of caffeine (a doubling of the previous concentration at each addition) until an increase in the resting tension equal to or greater than $1.0 \mathrm{~g}$ was attained. In chamber $V$ the procedure was the same except that the anaesthetic vapour was omitted.

At each incremental dose the increase (in grams) in the resting tension from the base-line was measured four minutes after the addition of the caffeine. The log dose-response curves (i.e., log caffeine vs. grams increase in resting muscle tension) were determined for each of the four inhalational anaesthetics. From these data the doses of caffeine required to raise the resting muscle tensions by $1.0 \mathrm{~g}$ were calculated. These 
TABLE III

Comparison of Caffeine Specific Concentrationsa Observed in the Presence of Various ANAESTHETICS

\begin{tabular}{|c|c|c|c|c|c|}
\hline \multirow{2}{*}{$\begin{array}{l}\text { Control } \\
\text { patients }\end{array}$} & \multicolumn{5}{|c|}{ Caffeine with } \\
\hline & - & Methoxyflurane & Enflurane & Isofiurane & Halothane \\
\hline \multicolumn{6}{|l|}{ Caffeine with } \\
\hline- & - & $1.68^{b}$ & $2.49^{*}$ & $3.14 \dagger$ & $8.46 \ddagger$ \\
\hline Methoxyflurane & $3.13 \dagger$ & - & 0.85 & 1.44 & $5.30 \ddagger$ \\
\hline Enflurane & $4.84 \ddagger$ & 2.04 & - & 0.62 & $3.80^{\dagger}$ \\
\hline Isoflurane & $4.84 \ddagger$ & $2.42 *$ & 0.55 & - & $2.82^{*}$ \\
\hline Halothane & $14.70 \ddagger$ & $9.52 \ddagger$ & $4.92 \ddagger$ & $3.25 \dagger$ & - \\
\hline
\end{tabular}

aThe concentration required to raise the resting skeletal muscle tension by one gram.

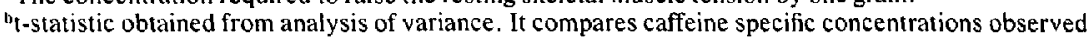
in the presence of two anaesthetics. The levels of statistical significance are based on Duncan's multiple range test. Contrasts for patients are shown above the diagonal, and for control subjects below it.

$* \mathrm{P}<0.05$.

$\dagger P<0.01$

$\$ \mathrm{P}<0.001$.

concentrations were designated the "caffeine specific concentrations". Thus an inverse relationship existed between the contracture amplitudes and the caffeine specific concentrations.

\section{Statistical evaluation}

The logarithms of the observed caffeine specific concentrations were subjected to analysis of variance. Logarithms were used to attain homogeneity of the variances.

Geometric means and their standard errors were calculated for each anaesthetic in both subject groups (Table II). Their designed comparisons are presented in the form of t-statistics (Tables II and III) which are based on the error variance estimated in the analysis of variance. Their statistical significance was evaluated by applying Duncan's multiple range test ${ }^{7}$ in which the effective number of groups was adjusted to allow for the limited number of comparisons made.

\section{REsults}

The caffeine specific concentrations for the control and for the MHS muscle in the absence and in the presence of methoxyflurane, isoflurane, enflurane and halothane are shown in Table II. The statistical evaluation of these data is given in this table and in Table III.

Caffeine contractures without and with the addition of any of the four anaesthetic vapours are statistically significantly higher (i.e., caffeine specific concentrations are lower) in the MHS than in the control muscle (Table II). The con- trasts between the control and the MHS muscle are about the same for all drug combinations. For all four anaesthetics the degree of increase of the contracture is about the same in the control as in the MHS muscle. For both the MHS and the control muscle the caffeine contractures are from greatest to least:

halothane $>$ isoflurane $>$ enflurane $>$ methoxyflurane.

Statistical examination of the relationships among the caffeine specific concentrations in the presence of the various anaesthetics shows significant differences for the comparisons of halothane with the other three anaesthetics, but for the most part the comparisons among methoxyflurane, enflurane and isoflurane are not statistically significant.

\section{Discussion}

The data suggest that methoxyflurane produces such a weak increase in caffeine contractures that it might be capable of inducing only very mild in vivo $\mathrm{MH}$ reactions. Enflurane and isoflurane, on the other hand, might be expected to precipitate more serious reactions but still not so fulminant as those triggered by halothane. These in vitro findings support the report of Harrison ${ }^{8}$ that methoxyflurane in vivo does not induce hyperthermic and/or rigid reactions in MHS swine. The values at first glance appear to be at variance with the observed in vivo human mortality data (Table I); however, further investigation of the human patients who developed $\mathrm{MH}$ reactions following the use of methoxyflurane re- 
vealed that, in nearly all, triggering skeletal muscle relaxants were employed, for example, succinylcholine or d-tubocurarine. It may have been that these latter drugs in combination with a weak additive or potentiating action of methoxyflurane were responsible for the observed $\mathrm{MH}$ reactions. The longer persistence of methoxyflurane within the body, because of its greater solubility in lipid tissues, as compared with the other inhalational agents examined in this study, may also have helped to account for the high mortality observed once $\mathrm{MH}$ reactions have commenced during methoxyflurane anaesthetics.

\section{REFERENCES}

1. Briti, B.A., Kwong, F.H.-F. \& Endrenyi, L. The Clinical and laboratory features of malignant hyperthermia management - a review. In: Malignant Hyperthermia, Current Concepts (ed. Henschel, E.O.), Appleton-Century-Crofts, New York (1977).

2. BRITT, B.A. Malignant hyperthermia - 1977. In:
Complications in Anaesthesiology (eds. Orkin, F.K. and Cooperman, L.H.), J.B. Lippincott Co., Philadelphia, $\mathrm{Pa}$.

3. Kalow, W., Britt, B.A.\& Richter A. The caffeine test of isolated human muscle in relation to malignant hyperthermia. Canad. Anaesth. Soc. J. 24: (6) 678 (1977).

4. Britt, B.A., Endrenyi, L., Kalow, W. \& PeTERS, P.L. The adenosine triphosphate (ATP) depletion test: comparison with the caffeine contracture test as a method of diagnosing malignant hyperthermic susceptibility. Canad. Anaesth. Soc. J. 23 : (6) 624 (1976).

5. Britt, B.A., Endrenyi, L., Scott, E. \& Frodis, W. Effect of temperature, time, and fascicle size on the caffeine contracture test. Canad. Anaesth. Soc. J., 27: I (1980).

6. Britt, B.A., Kalow, W., Gordon, A., HumPhrey, J.G. \& RewCastle, N.B. Malignant hyperthermia - an investigation of five patients. Canad. Anaesth. Soc. J. 20:431 (1973).

7. DUNC.AN, D.B. Multiple range and multiple F-tests. Biometrics /I: 1-42 (1955).

8. HARrison, G.G. A pharmacological in virro model of malignant hyperpyrexia. S. Afr. Med. J. 47: 774 (1973).

\section{RÉSUMÉ}

On a comparé les effets potentialisateurs de l'halothane, de l'enflurane, de l'isoflurane et du méthoxyflurane sur la réponse à la stimulation par caféine du muscle normal et du muscle de sujets susceptibles à l'hyperthermie maligne. La réponse à la caféine s'est avérée plus importante chez les sujets susceptibles à l'hyperthermie que chez ceux présentant un muscle normal, et ceci indépendamment de la présence ou de l'absence de l'un des anesthésiques comparés. La différence entre la réponse du muscle normal et celle du muscle de sujets anormaux était à peu près la mème avec les quatre agents étudiés. La potentialisation de l'effet de la caféine était à peu près la même avec les quatre anesthésiques pour le muscle normal et l'anormal, l'halothane étant le plus actif, suivi de l'isoflurane, de l'enflurane et du méthoxyfiurlane. L'examen des rapports entre les concentrations spécifiques de caféine en présence des quatre ancsthésiques montre des différences significatives entre l'halothane et les trois autres, mais non entre les trois autres. 